\title{
Assessment of Anthropogenically Stressed Ecosystem of Port Waters Using Macrobenthic Community-Biotic Indices
}

\author{
Sigamani Sivaraj ${ }^{1, *}\left(\mathbb{D}\right.$, Durga Prasad Behera ${ }^{1}\left(\mathbb{D}\right.$, Kolandhasamy Prabhu $^{1}(\mathbb{D})$ \\ ${ }^{1}$ Gujarat Institute of Desert Ecology, Coastal and Marine Ecological Division, Bhuj, Gujarat, India.
}

\section{How to cite}

Sivaraj, S., Behera, D.P., Prabhu, K. (2022). Assessment of Anthropogenically Stressed Ecosystem of Port Waters Using Macrobenthic CommunityBiotic Indices. Turkish Journal of Fisheries and Aquatic Sciences, 22(1), TRJFAS19539. http://doi.org/10.4194/TRJFAS19539

\section{Article History}

Received 24 March 2021

Accepted 12 August 2021

First Online 17 August 2021

\section{Corresponding Author}

Tel.: +02832235026

E-mail: sivabiotech007@gmail.com

\section{Keywords}

Macrobenthic fauna

Vizag port

Anthropogenic

$\mathrm{AMBI}$ indices

Ecosystem

\begin{abstract}
Macrobenthic community being used as marine health indictor vis-à-vis to anthropogenic disturbance since their characteristic of life cycle (reproductive mode, sedentary, energy transfer, sensitive-resistance species, indicator organism etc.). Therefore, the present study was chosen in Vizag port waters have been subject to a variety of anthropogenic pressure in the last two decades. The purpose of this study was to assess the ecological status of the port environment through biotic indices like AZTI 's Marine Biotic Index (AMBI) and Multivariate-AMBI Index (M-AMBI) which have been successfully validated geographically and anthropogenically stressed habitats. The result revealed that the inner harbor (IHC, Iron ore Q1 \& Iron ore Q7) stations are heavily disturbed while the outer harbor fall between undisturbed and moderately disturbed status. It was observed that the reduced tidal action inside the harbor determines the health status indicating that the Iron ore transporting areas are at high risk with respect to benthic population.
\end{abstract}

\section{Introduction}

Estuaries and coastal waters are significantly polluted by anthropogenic activities. The port environment is generally polluted because of its operations, as the transport hub for a variety of materials includes coal, crude oil, minerals, fertilizer besides continuous navigation dredging as well as extension/construction activities. The harbor environment changes its physio-chemical characteristics by chemicals and oils, suspended solids during transport, removal of ballast waters and dredging operations (Trozzi \& Vaccaro, 2000). The changes in the water, the faunal group in this particular ecosystem, leading to biodiversity to slowly decline.
It is essential to determine the health of an ecosystem; both from a port management authority and from a scientific point of view, and also to streamline the operations more sustainably. The Vizag port is a natural harbor which is a semi-enclosed body of water, offers ship entry in indoor harbor with holding the capacity of Dead Weight Tonnage (DWT) up to 3600 DWT, and accommodates up to 2,00,000 DWT in outdoor harbor with multipurpose installations involving transportation and ship repair facilities. The dredging operation is done periodically to hold the navigation channel depth up to $12-15 \mathrm{mts}$. The port environment receives industrial and domestic effluents from the port premises as well as from the rapidly growing urban and industrial population. 
Benthic macrofauna plays a vital role for monitoring and assessment of ecosystem changes due to the sedentary habit (Reiss \& Kröncke, 2005) and species richness and tolerances to habitat disturbances (Pinto et al., 2009; Dauvin et al., 2010; Sivaraj et al., 2015). Their relatively long life span (Reiss \& Kröncke, 2005; Sivadas, 2009) and their role in the food web of aquatic systems make them an ideal tool for ecosystem monitoring (Murugesan et al., 2011). Among the recent biotic indices developed to assess the marine environment (Sivaraj et al., 2015) AZTI's Marine Biotic Index (AMBI) (Borja et al., 2000) and Multivariate-AMBI (M-AMBI) (Muxika et al., 2007) have been effectively tested from different anthropogenic and geographic location for proper evaluation of ecosystem (Ana et al., 2012). The aim of the present study is to assess the Vizag port ecosystem using the macro benthic indices to evaluate the environmental health in terms of healthy or polluted.

\section{Materials and Methods}

\section{Study Area and Sampling Site Fixation}

Vizag Port bordered by the Dlphino 's Hill in the southern arm and Rose Hill in the northern arm of the state of Andhra Pradesh plays a significant role in India 's eastern coast economy. This hill layout prevents the heavy tide and holds $1.8 \mathrm{mts}$ of tidal area. The port is subdivided into an inner and outer harbour, containing 24 berths for coal and iron ore handling. During the monsoonal season, a significant amount of freshwater reaches the harbor through the Meghadrigedda river which brings effluents from major industries situated in its vicinity besides the water from the nearby township.
For the present investigation 10 sampling stations were fixed (Figure 1) which will be represented by their station's through the manuscript (Table 1).

\section{Sample Collection and Laboratory Analysis}

Triplicate sediment samples were collected from the study site from January 2018 up to December 2019 using van Veen grab $\left(0.04 \mathrm{~m}^{2}\right)$. The sediment samples were used through a $0.5 \mathrm{~mm}$ sieve. The larger organism was handpicked and preserved with a $5 \%$ formalin solution and then added 4-5 drops of rose bengal solution to increase visibility during identification under the microscope. All organisms were identified at the lowest possible taxonomic level following reference keys (Fauvel, 1953; Day, 1967; Subba Rao et al., 1991; Ramakrishna,2003;http://www.marinespecies.org/poly chaeta/). Sediment samples were collected at each station to analyze the soil texture (Krumbein \& Pettijohn, 1938) and the total organic carbon (El Wakeel \& Riley, 1956). Water samples were collected for the measurement of temperature, salinity, $\mathrm{pH}$ in situ and for the laboratory analysis of dissolved oxygen (DO), biological oxygen demand (BOD), turbidity (nefloturbidometer); total suspended solids (TSS) nitrite (NO2), nitrate (NO3), reactive silicate (SIO4) were analyzed by the standard methods by Sujata et al. (2012).

\section{Data Analysis}

Appropriate statistical software was used to interpret physico-chemical and biological variables. Statistical software such as PRIMER (Clarke \& Gorley, 2006) and XLSTAT-Pro version 5.1.4 (@ Addinsoft) have

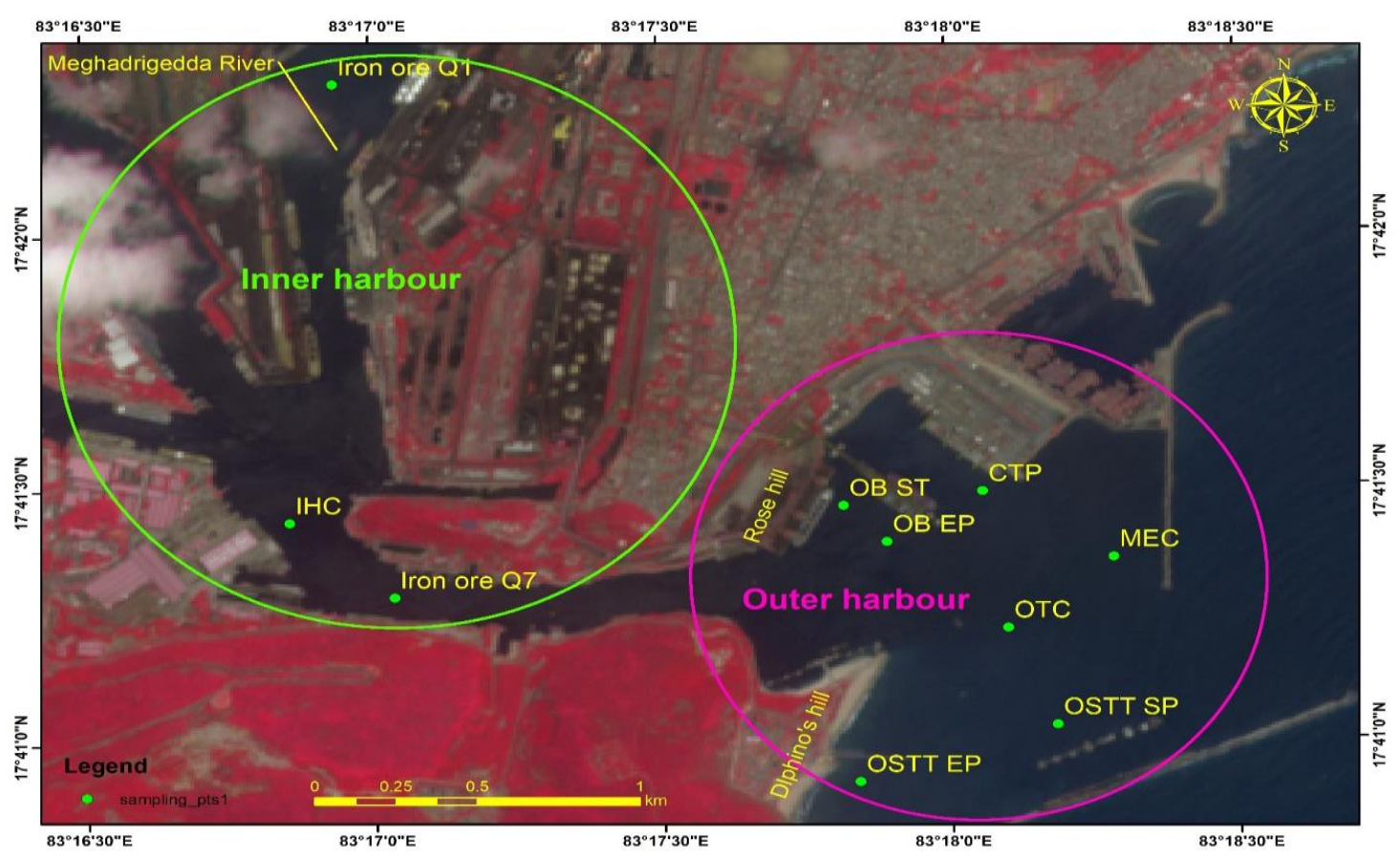

Figure 1. Map showing the study area. 
Table 1. Sampling location and their stations codes of Vizag Port waters

\begin{tabular}{lll}
\hline Location & Station & Stations Codes \\
\hline Inner Harbor & Inner Harbour Circle & IHC \\
& Iron Ore Berth West Q-I & Iron ore Q1 \\
Iron Ore Berth West Q-7 & Iron ore Q7 \\
Outer Harbor & Ore Berth Start point & OB ST \\
& Ore Berth End point & OB EP \\
& Container Terminal Point & CTP \\
& Mouth Entrance Channel & MEC \\
& Outer Turning Circle & OTC \\
& Jetty Near OSTT Start Point & OSTT SP \\
& Jetty Near OSTT End Point & OSTT EP \\
\hline
\end{tabular}

been used in this study. Briefly, for cluster and MDS analysis, benthic abundance data were pre-treatment to transform the total under the fourth root, followed by Bray-Curtis similarity to the cluster matrix. As a consequence, this matrix was transformed into a nonmetric multidimensional scaling (nMDS) ordination to analyze the spatial distribution of benthic assemblies along port waters. The principal component analysis was performed on the abiotic factors to analyze the distribution pattern between stations and environmental variables.

\section{Benthic Indices}

The ecological health of an ecosystem assessed by using $A M B I$ and $M-A M B I$ indices (Borja et al., 2000) in which the distribution of benthic faunal abundances was considered for grouping ecological groups (EG) in accordance with the pollution gradient into EGI (species very sensitive to organic enrichment and present under unpolluted conditions); EGII - (species are present in very low density and relatively constant in abundance over time, unaffected by pollution); EGIII (species tolerant to excess organic matter enrichment); EGIV - (second-order opportunistic species-slightly to pronounced unbalanced situations); and EGV - (firstorder opportunistic species-pronounced unbalanced situations). The multivariate $\mathrm{AMBI}$ (M-AMBI) was suggested by Borja et.al. (2000) and then Muxika et al. (2007) with the inclusion of Shannon's diversity, richness and $A M B I$, into a factor analysis (FA). The defined state of reference at 'high' considered as an optimum where the M-AMBI approaches 1. At 'bad' status, the M-AMBI approaches 0 . The present study, threshold values for the M-AMBI classification were derived based on the recommendation by Muxika et al. (2007). The reference values are as follows: 'High' quality, >0.80; 'Good', 0.570.80; 'Moderate', 0.38-0.57; 'Poor', 0.20-0.38; and 'Bad', <0.20.

\section{Results}

The environmental parameters recorded in the present study are shown in Table 2. The water temperature, salinity, $\mathrm{pH}$ and $\mathrm{DO}$ were recorded with a minimum of $27^{\circ} \mathrm{C}(\mathrm{IH}), 32 \mathrm{ppt}(\mathrm{IH}), 8.31$ (Iron ore Q1) and $2.8 \mathrm{mg} / \mathrm{I}$ (Iron ore Q7) while maximum at OSTTSP $\left(31^{\circ} \mathrm{C}\right.$, $36 \mathrm{ppt}, 8.43$ and $6.1 \mathrm{mg} / \mathrm{l})$. BOD minimum was recorded in OSTTEP (0.97) and maximum in Iron ore Q7 (2.51); TSS lower in OTC (55.64) higher in Iron ore Q7 (172.80); Turbidity low in OSTTSP (8.78) and high in Iron ore Q7 (16.74); $\mathrm{NO}_{2}$ and $\mathrm{NO}_{3}$ was minimum in OTC (1.33) and OSTTSP (3.14) while maximum in Iron ore Q7 (3.42) and Iron ore Q1 (13.54). $\mathrm{SiO}_{3}$ lower in OSTTSP (10.54) and higher in IH (52.37). The sediment characteristic like sand, silt and clay were maximum at OSTTEP (83.6\%), OTC (18.52\%) and Iron ore Q1 (16.71\%) and minimum at Iron ore Q1 (60.54\%), OBEP (10.22\%) and OTC (4.6\%). TOC was higher in Iron ore Q1 (14.6mgc/g) and lower in OSTTEP (7.23mgC/g).

\section{Cluster and MDS Analysis}

Cluster and MDS study was performed on the data of benthic faunal abundance of the Vizag port waters. The result showed that the inner harbour stations IHC, Iron ore Q1 and Iron ore Q7 are grouped as a separate cluster with a high similarity while the outer harbour formed a separate cluster as shown in Figure 2a. The data were further confirmed via MDS, resulting in the grouping as separate cluster for the inner and outer harbors (Figure $2 b$ ).

\section{Principal Component Analysis (PCA)}

PCA was drawn to assess the correlation between the observed physico-chemical parameters and stations sampled. The results showed that out of the $89.95 \%$ of the total variance, $84.72 \%$ for $\mathrm{F} 1$ and $5.23 \%$ for $\mathrm{F} 2$ axis (Figure 3). The parameters like $\mathrm{BOD}, \mathrm{NO}_{2}, \mathrm{NO}_{3}$, Turbidity, TSS, Silicate showed strong correlation with stations IHC, Inner ore Q1 \& Q7, OBSP, OBEP and CTP whereas water temperature, salinity, $\mathrm{pH}$, and $\mathrm{DO}$ had weak correlation with stations OSTTSP, OSTTEP, OTC, and MEC. With respect to sediment parameters, axis showed the total variance of $85.27 \%$ (F1-68.84\% \& F2-16.43\%) (Figure 4). The $\mathrm{pH}$ and sand fraction were more correlated to the stations OSTTSP, OSTTEP, OTC, CTP, and OBEP while silt clay and TOC associated with Inner ore Q1 \& Q7, MEC, IHC, and OBST. 
Table 2. Physico-chemical parameters recorded in Vizag port waters

\begin{tabular}{|c|c|c|c|c|c|c|c|c|c|c|c|c|c|c|}
\hline & IH & Iron ore Q1 & Iron ore Q7 & OB ST & OB EP & CTP & MEC & OTC & OSTT SP & OSTT EP & Max & Min & Mean & SD \\
\hline Water tem ${ }^{\circ} \mathrm{C}$ & 27 & 27 & 28 & 28 & 27 & 27.2 & 28 & 28.5 & 31 & 30.5 & 31 & 27 & 28.35 & 1.44 \\
\hline Salinity (PSS) & 32 & 32.5 & 33 & 33 & 33.5 & 34 & 34.4 & 35.6 & 36 & 35.2 & 36 & 32 & 33.93 & 1.36 \\
\hline $\mathrm{pH}$ & 8.18 & 8.13 & 8.30 & 8.20 & 8.32 & 8.34 & 8.31 & 8.39 & 8.43 & 8.40 & 8.43 & 8.13 & 8.30 & 0.10 \\
\hline $\mathrm{DO}(\mathrm{mg} / \mathrm{l})$ & 4.1 & 5.1 & 2.8 & 5.6 & 4.8 & 5.3 & 6.0 & 5.6 & 6.1 & 6.0 & 6.1 & 2.8 & 5.03 & 1.03 \\
\hline BOD (mg/l) & 2.17 & 2.43 & 2.51 & 1.97 & 2.05 & 2.01 & 1.54 & 1.07 & 1.01 & 0.97 & 2.51 & 0.97 & 1.77 & 0.58 \\
\hline TSS (ppm) & 90.00 & 172.80 & 123.60 & 98.40 & 101.20 & 82.47 & 70.65 & 55.64 & 65.21 & 70.12 & 172.80 & 55.64 & 96.54 & 34.50 \\
\hline Turbidity (NTU) & 14.54 & 15.24 & 16.74 & 12.00 & 13.54 & 12.00 & 12.50 & 9.00 & 8.78 & 11.47 & 16.74 & 8.78 & 12.61 & 2.55 \\
\hline $\mathrm{NO}_{2}(\mu \mathrm{mol} / \mathrm{l})$ & 3.34 & 2.84 & 3.42 & 2.11 & 2.56 & 3.01 & 2.14 & 1.33 & 1.78 & 1.67 & 3.42 & 1.33 & 2.41 & 0.72 \\
\hline $\mathrm{NO}_{3}(\mu \mathrm{mol} / \mathrm{l})$ & 12.41 & 13.54 & 10.47 & 9.45 & 7.45 & 10.24 & 4.64 & 4.38 & 3.54 & 3.14 & 13.54 & 3.14 & 8.00 & 3.82 \\
\hline $\mathrm{SIO}_{3}(\mu \mathrm{mol} / \mathrm{l})$ & 52.37 & 33.44 & 44.23 & 31.25 & 31.65 & 29.08 & 28.77 & 24.36 & 10.54 & 11.35 & 52.37 & 10.54 & 30.00 & 12.82 \\
\hline Sediment $\mathrm{pH}$ & 8.12 & 8.21 & 8.28 & 8.00 & 8.23 & 8.34 & 8.26 & 8.12 & 8.32 & 8.40 & 8.40 & 8.00 & 8.22 & 0.12 \\
\hline Sand (\%) & 68.23 & 60.54 & 66.84 & 71.88 & 79.51 & 73.58 & 71 & 76.88 & 80.23 & 83.6 & 83.60 & 60.54 & 73.04 & 7.02 \\
\hline Silt (\%) & 16.35 & 22.75 & 18.56 & 15.24 & 10.22 & 15.88 & 20.4 & 18.52 & 14.37 & 10.3 & 22.75 & 10.22 & 16.30 & 4.03 \\
\hline Clay (\%) & 15.42 & 16.71 & 14.6 & 12.88 & 10.27 & 10.54 & 8.6 & 4.6 & 5.4 & 6.1 & 16.71 & 4.60 & 10.54 & 4.33 \\
\hline $\mathrm{TOC}(\mathrm{mgC} / \mathrm{g})$ & 10.3 & 14.6 & 10.3 & 12.4 & 9.0 & 8.7 & 10.2 & 7.8 & 8.5 & 7.23 & 14.6 & 7.2 & 10.07 & 2.21 \\
\hline
\end{tabular}

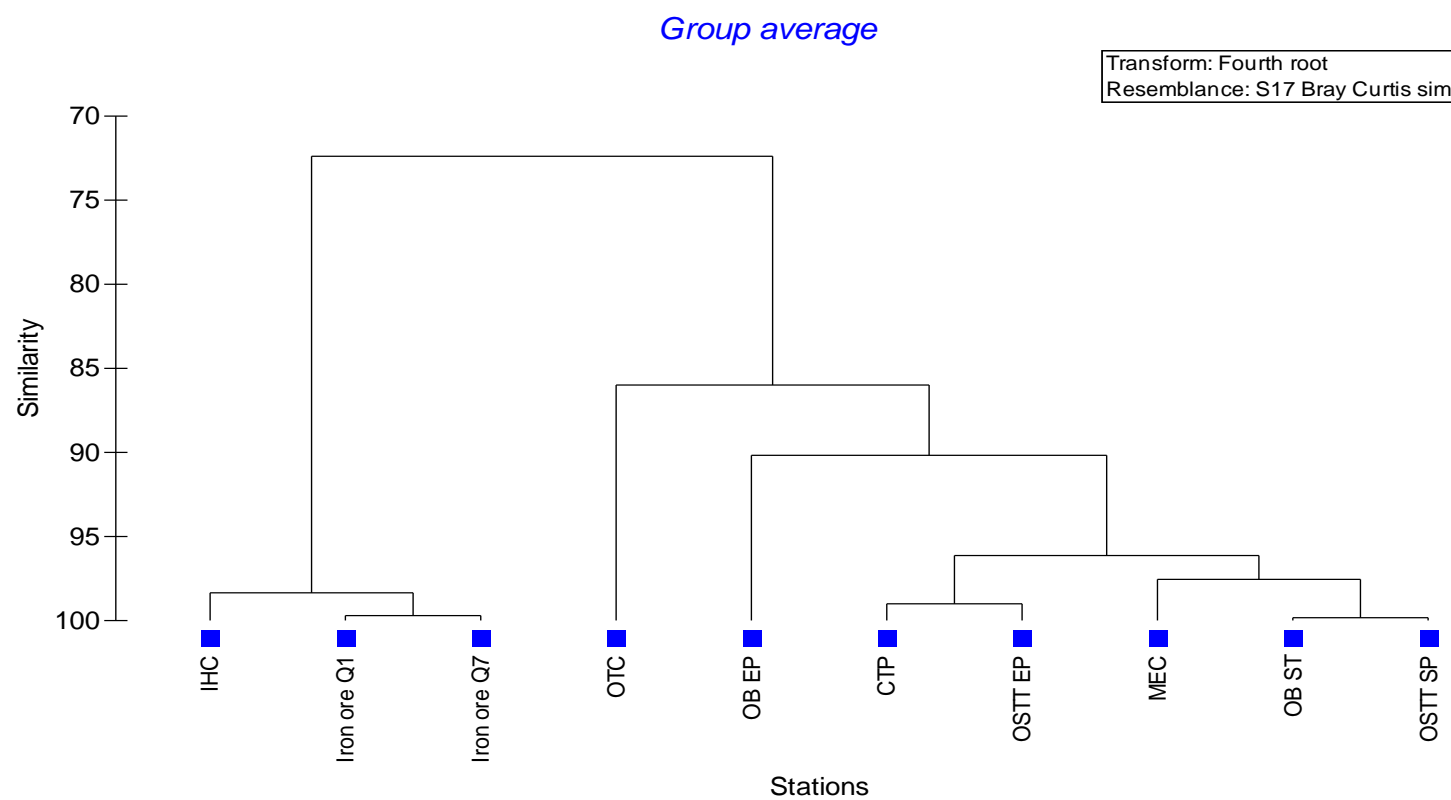

Figure 2a. Cluster analysis of benthic faunal abundance in Vizag port waters

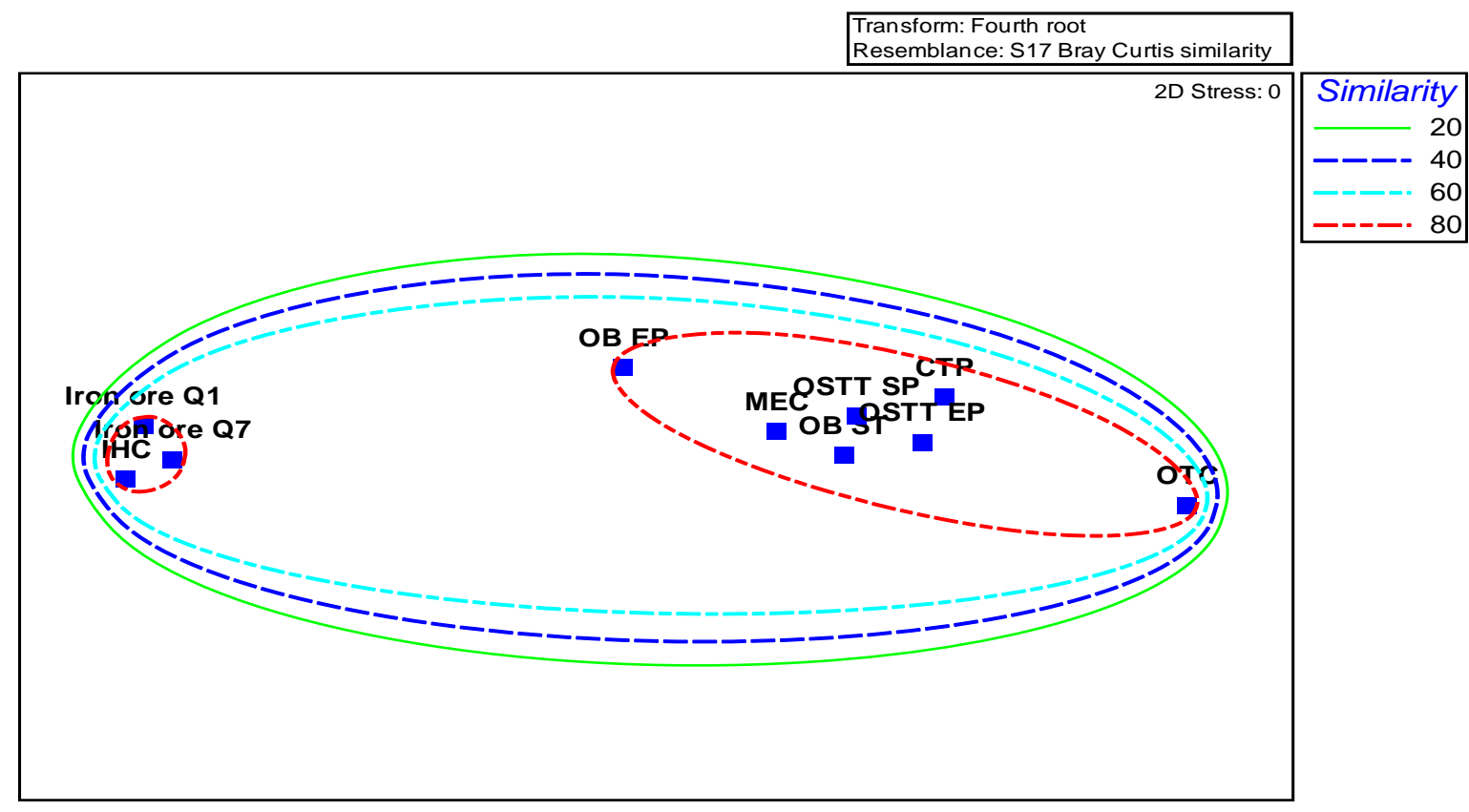

Figure $\mathbf{2 b}$. MDS analysis of benthic faunal abundance in Vizag port waters 


\section{Benthic Indices}

Totally 81 macrobenthic species were identified in this survey of which 72 species were found fitting into the Ecological Group (EG) (very sensitive to opportunistic species) and the remaining 7 species were not assigned based on AZTI classification. Of the total 72 species, 22 species (27.5\%) were fall under group EG-1; 21 species (17.38\%) belonged to EG-2; 14 species (12.21\%) to EG-3; 13 species (22.21\%) to EG-4; 2 species (20.27\%) EG-5. The remaining 7 species (7.74 \%) were not classified under an ecological group in the AZTI software and are currently labelled as "not assigned."

Benthic faunal abundance data ran in the AMBI indices, the result predicted that the Vizag port waters fall in the range from undisturbed (0.91) to heavily disturbed (5.16) (Table 3). It is understood that the inner harbor stations were heavily disturbed, especially IHC (5.16), Iron ore Q1 (5.14) and Iron ore Q7 (5.06) were heavily disturbed. In the case of outer harbor, stations OBSP (3.60) and OBEP (3.57) fall into moderately disturbed group while CTP (1.24) and OTC (1.86) into slightly disturbed. The stations MEC (0.91), OSTTSP (1.03) and OSTTEP (1.07) grouped as undisturbed based on $\mathrm{AMBI}$ values. Likewise, $\mathrm{M}-\mathrm{AMBI}$ value ranged between 0.660 and 0.969 and the ecological health status varied between "good" and "high" status. The inner harbor was in the status of "good" condition while the outer harbor in "high" status except for the station OBSP (good condition).

\section{Discussion}

Vizag port has been reported to be impacted by sewage disposal and continuous port activities (Raman \& Ganapati, 1983; Pati et al., 2013; Pati \& Rao, 2015). The present study result from the inner and outer harbor areas through PCA analyses indicated that the stations IHC, Iron ore Q7 and Iron ore Q1 (Inner Harbour) were positively correlated with Turbidity, TSS, $\mathrm{SiO} 3, \mathrm{No} 3$ and BOD (Figure 3). The high content of these physiochemical parameters was reported at inner harbor due to the influx of domestic waste coupled with industrial effluents through the Meghadrigedda river. The PCA showed that TOC, clay and silt content were strong correlated with IHC, Iron ore Q7 and Iron ore Q1 (Inner Harbour stations) (Figure 4). The fertilizer and iron ore berths located in the inner as well as discharge of the effluents may increase the concentration of silt fraction and nutrients (Amar et al., 2015) in the water. In addition, high organic matter accumulation in the inner harbor could be the result of slow tidal movement (Ram et al., 2009; Jyoti et al., 2017) inside the harbour. The cluster and MDS analysis using the benthic faunal abundance, showed that the inner harbor (IHC, Iron ore Q7 and Iron ore Q1) was grouped into cluster 1 while the other stations formed cluster 2 based on the rate of impact by pollutants. This type of cluster was in agreement with Sivaraj et al. (2015) where the stations located near wastewater disposing site and agriculture runoff got grouped in cluster1. Likewise, the inner harbor locations were fixed near the sewage disposal and fertilizer loading berth are considered as heavily affected and clustered together.

In the recent times, the ecological quality of estuarine and coastal waters was assessed by the variety of benthic indices (Chainho et al., 2007; Labrune et al., 2006). Comparing the indices, $A M B I$ and $M-A M B I$ indices developed by Borja et al. (2000) and Muxika et al. (2007) were efficiently tested in the different anthropogenically stressed ecosystem. Even though these indices were developed to assess the European coastal waters, its applicability extended to the developing countries and well tested in the southeast coast (Khan et al., 2014; Sivaraj et al., 2015; Feebarani et al., 2016) and southwest (Sivaraj et al., 2014; Sivadas et al., 2016) coast of India.

The ecological health of $\mathrm{AMBI}$ indices indicated that stations IHC (5.16), Iron ore Q1 (5.14) and Iron ore Q7 (5.06) were heavily disturbed; OB SP (3.60), OB EP (3.57) were moderately disturbed; CTP (1.24), OTC (1.86) were slightly disturbed; MEC (0.91), OSTT SP (1.03) and OSTT EP (1.07) were undisturbed. The heavily disturbed sites are receiving the effluents from large, medium and small industries operating in the area. There exists a gradation of the impact by the pollutants in the area in the decreasing order from the inner harbor to the outer harbor stations (Raman \& Ganapati, 1983 \& 1986; Balaji, 1988; Tripathy et al., 2005) which could be reflected in the results of the various analyzer. The accumulation of organic matter in the inner harbor zones favors the dominance of the opportunistic species EG-IV\&V Capitella capitata, Cirratulus sp., Cirratulus chrysoderma and Prionospio pinnata in those stations (Ergen et al., 2006; Çinar et al., 2012; Sivaraj et al., 2015; Sigamani et al., 2019) while in outer harbor is comparatively low may flushed out the pollutant into the open sea waters (Ram et al., 2009; Jyoti et al., 2017). Similar results were reported by Sivadas (2009) from Mormugao harbor.

The stations OB SP (3.60) and OB EP (3.57) were found as moderately disturbed owing to the presence of predominant species like Ficopomatus enigmaticus, Prionospio cirrobranchiata, Sternaspis scutata belonging to ecological groups (EG-III \& IV). Other stations CTP (1.24), OTC (1.86) and MEC (0.91), OSTT SP (1.03), OSTT EP (1.07) were classified as between the category of slightly disturbed to undisturbed with the representative species of EG I and EG II such as Magelona sp., Maldane sp., Anomia sp., Assiminea sp., Ampithoe rubricate, Angeliera phreaticol and Gammarus sp. This result is in conformity with the observations of Venturini et al. (2004) who reported the dominance of the ecological group (EG I \& EG II) in the slightly and undisturbed sites. 
Table 3. Ecological health classification of Vizag port water using AMBI indices

\begin{tabular}{|c|c|c|c|c|c|c|c|c|c|c|c|c|c|}
\hline Stations & 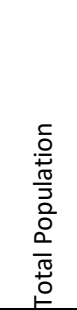 & 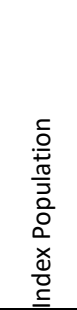 & 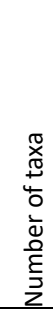 & 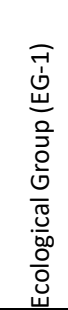 & 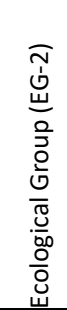 & 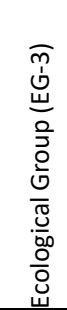 & 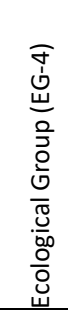 & 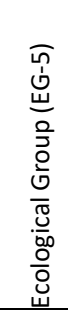 & 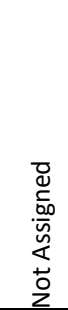 & $\sum_{<}^{\bar{\infty}}$ & 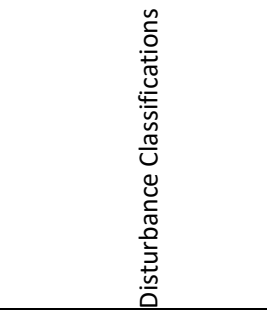 & 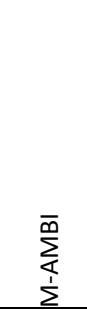 & $\begin{array}{l}\sum_{n}^{n} \\
\stackrel{n}{n} \\
\end{array}$ \\
\hline $\mathrm{IHC}$ & 2186 & 2148 & 44 & 0.7 & 1 & 11.8 & 26.5 & 60 & 1.7 & 5.16 & Heavily Disturbed & 0.660 & Good \\
\hline Iron ore Q1 & 1939 & 1918 & 44 & 0.9 & 1.4 & 9.3 & 30.6 & 57.9 & 1.1 & 5.14 & Heavily Disturbed & 0.668 & Good \\
\hline Iron ore Q7 & 1894 & 1820 & 43 & 0.9 & 1.2 & 15 & 25.6 & 57.4 & 3.9 & 5.06 & Heavily Disturbed & 0.675 & Good \\
\hline OB SP & 226 & 216 & 36 & 11.6 & 13 & 15.7 & 43.1 & 16.7 & 4.4 & 3.60 & Moderately disturbed & 0.782 & Good \\
\hline OB EP & 466 & 426 & 44 & 4.5 & 22.3 & 15.3 & 46.2 & 11.7 & 8.6 & 3.57 & Moderately disturbed & 0.868 & High \\
\hline СТP & 169 & 145 & 38 & 53.1 & 24.8 & 9.7 & 11 & 1.4 & 14.2 & 1.24 & Slightly disturbed & 0.926 & High \\
\hline MEC & 273 & 245 & 41 & 56.7 & 31.4 & 6.1 & 5.7 & 0 & 10.3 & 0.91 & Undisturbed & 0.969 & High \\
\hline ОтС & 78 & 65 & 35 & 40 & 18.5 & 20 & 20 & 1.5 & 16.7 & 1.86 & Slightly disturbed & 0.880 & High \\
\hline OSTT SP & 223 & 201 & 40 & 52.2 & 33.3 & 7.5 & 7 & 0 & 9.9 & 1.03 & Undisturbed & 0.946 & High \\
\hline OSTT EP & 183 & 171 & 39 & 54.4 & 26.9 & 11.7 & 6.4 & 0.6 & 6.6 & 1.07 & Undisturbed & 0.941 & High \\
\hline
\end{tabular}

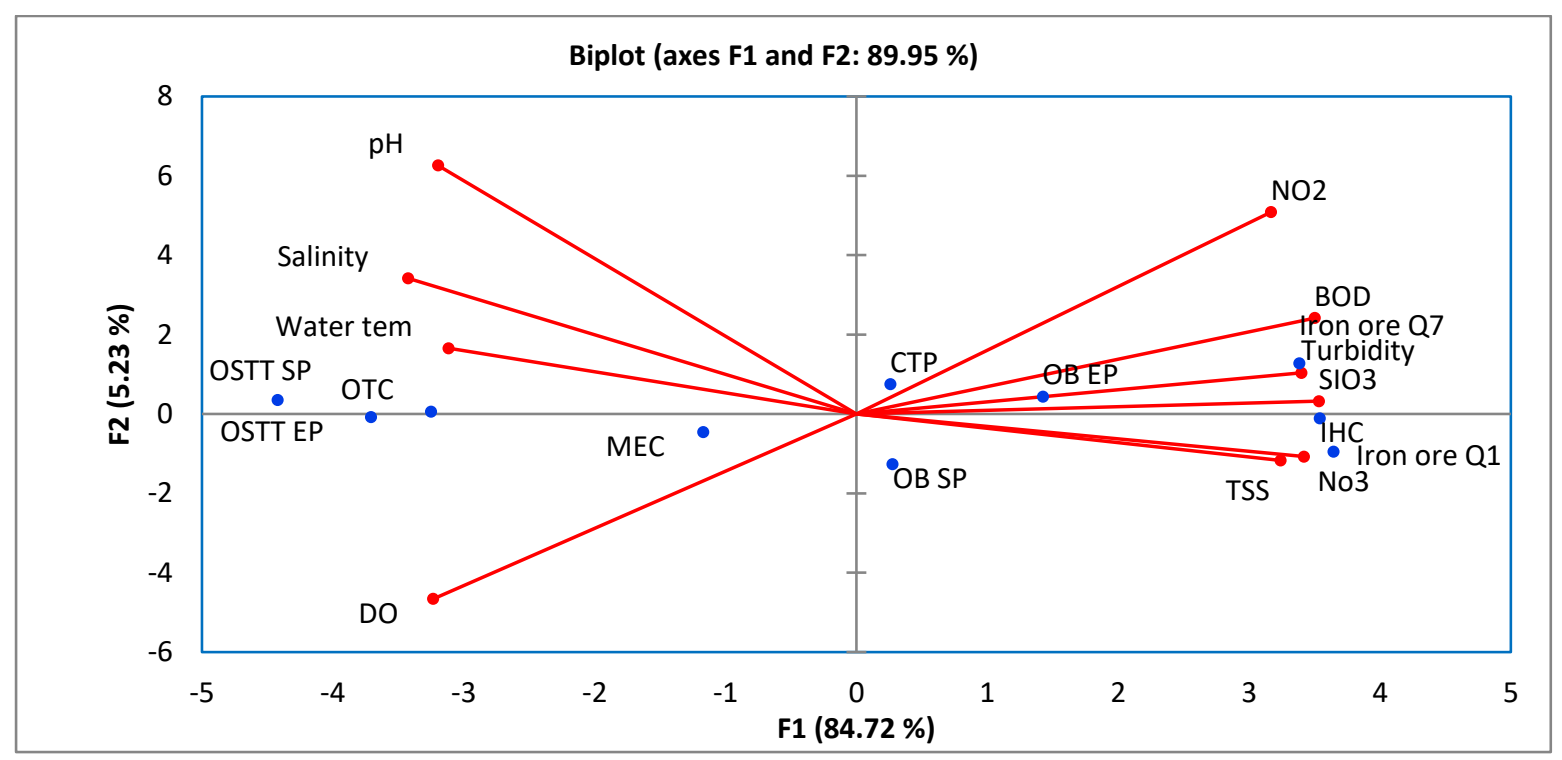

Figure 3. Principle component analysis-biplot of physico-chemical parameters of water in Vizag port waters

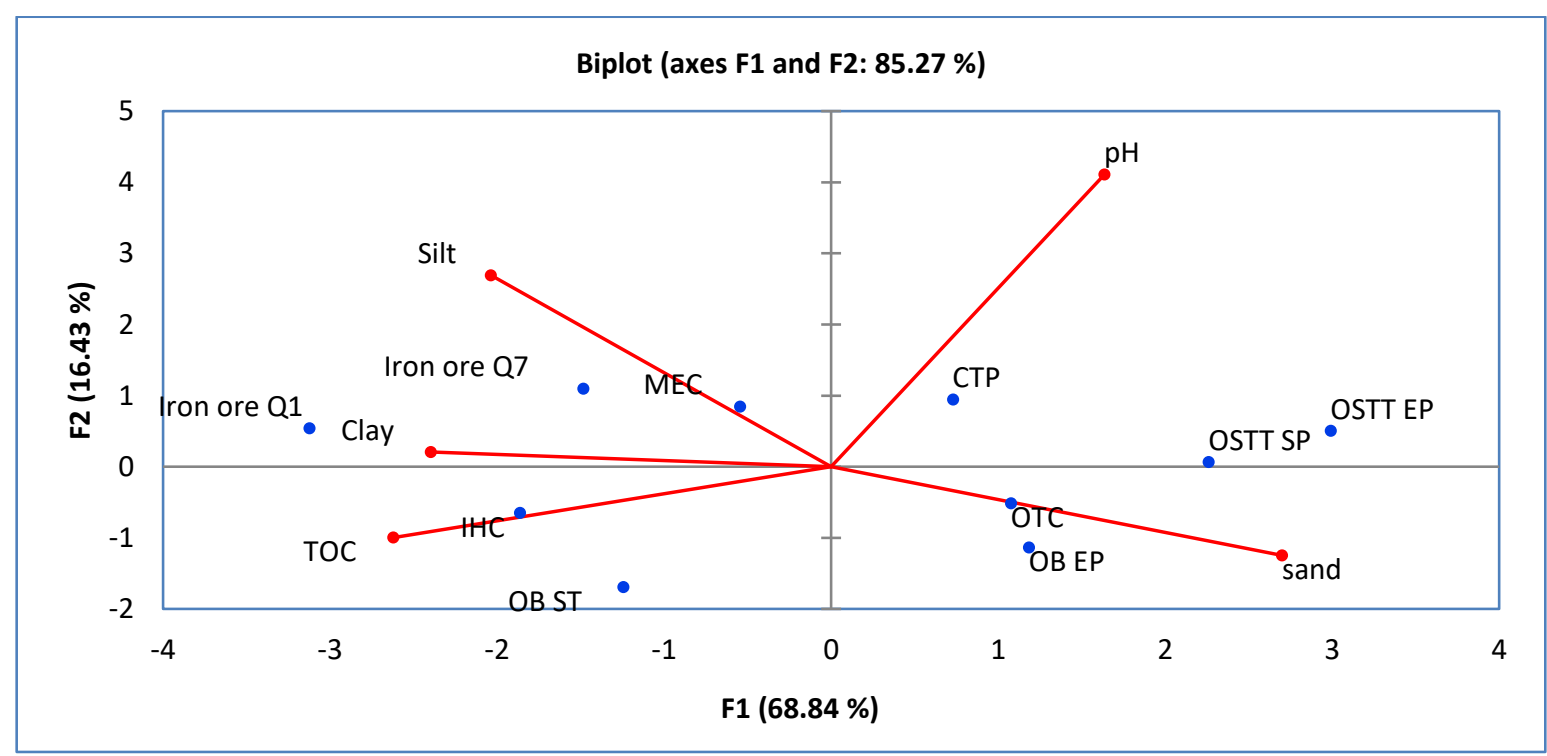

Figure 4. Principle component analysis-biplot of sediment parameters in Vizag port waters 


\section{Conclusion}

The ecological status of Vizag port water assessed using benthic indices and the correlation analysis of physico-chemical parameter concluded that the inner harbor was heavily polluted as a result of effluents from the Meghadrigedda river coupled with port activities as well as low tidal action. The outer harbor is "Moderately" to "Undisturbed," status as the pollutants effects are reduced by tidal action which remove the pollutants. The study therefore demonstrated the efficiency of benthic indices in evaluating the anthropogenically stressed ecosystem, but we encourage the use of a variety of indices and methods that are highly recommended in the near future for assessment of ecosystem status.

\section{Ethical Statement}

Not applicable.

\section{Funding Information}

The corresponding author of this article greatly thanks the Science and Engineering Research Board (SERB) (File No.PDF/2016/001096) Govt. of India for funding support.

\section{Author Contribution}

SS: Conceptualization and design the study, Data analysis and interpretation, Writing-original draft; DPB: Formal analysis and review; KP: Writing - review \& editing.

\section{Conflict of Interest}

The author(s) declare that they have no known competing financial or non-financial, professional, or personal conflicts that could have appeared to influence the work reported in this paper.

\section{Acknowledgements}

Authors are thankful to Prof. K. Kathiresan (Director) and P. Murugesan (Associate professor), CAS in Marine Biology, Annamalai University for providing the facilities.

\section{References}

Amar, S.M., Dattesh, V.D., Sawant, S.S., Venkat, K., Anil, A.C. (2015). Distribution and abundance of benthic macroorganisms in and around Visakhapatnam Harbour on the east coast of India. Journal of the Marine Biological Association of the United Kingdom, 95(2), 215-231. https://doiorg/101017/S0025315414001490

Ana, P., Valença, M.C., Paulo, J.P. (2012). Macrobenthic community for assessment of estuarine health in tropical areas (Northeast, Brazil): review of macrofauna classification in ecological groups and application of AZTI Marine Biotic Index. Marine Pollution Bulletin, 64(9), 1809-1820. https://doiorg/101016/jmarpolbul201206003.

Balaji, M. (1988). Investigations on biofouling at two ports in Andhra Pradesh, India and some aspects of toxicity of copper to the fouling bivalve, Mytilopsis sallei (Recluz). Ph. D. Thesis, Andhra University, Waltair.

Borja, A., Franco, J., Pérez, V. (2000). A marine biotic index to establish the ecological quality of soft-bottom benthos within European estuarine and coastal environments. Marine Pollution Bulletin, 40(2), 1100-1114. https://doiorg/101016/S0025-326X(00)00061-8

Chainho, P., Costa, J.L., Chaves, M.L., Dauer, D.M., Costa, M.J. (2007). Influence of seasonal variability in benthic invertebrate community structure on the use of biotic indices to assess the ecological status of a Portuguese estuary. Marine Pollution Bulletin, 54, 1586-1597. https://doiorg/101016/jmarpolbul200706009

Çinar, M.E., Bakir, K., Ozturk, B., Katağan, T., Dagli, E., Açik, S., Doğan, A., Bitlis, B., 2015. TUBI (Turkish Benthic Index): a new biotic index for assessing impacts of organic pollution on benthic communities. Journal of the Black Sea / Mediterranean Environment, 21 (2), 135-168.

Clarke, K.R., \& Gorley, R.N. (2006). Primer v6: User Manual/ Tutorial. PRIMER - E Ltd., Plymouth, United Kingdom, p.190.

Dauvin, J.C., Bellan, G., Bellan-Santini, D. (2010). Benthic indicators: from subjectivity to objectivity where is the line? Marine Pollution Bulletin, 60, 947-953. https://doiorg/101016/jmarpolbul201003028

Day, J.H. (1967). A monograph on the polychaeta of Southern Africa Parts I Errantia \& II Sedentaria Trustees of The British Museum (Natural history) London. p.878. https://doiorg/101017/S0025315400019299

El Wakeel, S.K., Riley, J.P. (1956). The determination of organic carbon in marine muds. Journal of the Council / Permanent International Council for the Exploration of the Sea, 22, 180-183. https://doiorg/101093/icesjms/222180

Ergen, Z., Çinar, M.E., Dagli, E., Kurt, G. (2006). Seasonal dynamics of soft-bottom polychaetes in Izmir Bay (Aegean Sea, eastern Mediterranean). Scientia Marina, 70, 197-205. https://doiorg/103989/scimar200670s3197

Fauvel, P. (1953). The fauna of India including Pakistan, Ceylon, Burma and Malaya. Annelida: Polychaeta, Allahabadp. 507

Feebarani, J., Joydas, T.V., Damodaran, R., Borja, A. (2016). Benthic quality assessment in a naturally- and humanstressed tropical estuary. Ecological Indicator, 67, 380390. https://doiorg/101016/jecolind201603005

Jyoti, M., Soniya, S., Tatiparthi, S., Tejal, V. (2017). Comparative efficacy of benthic biotic indices in assessing the Ecological Quality Status (EcoQS) of the stressed Ulhas estuary, India." Marine Pollution Bulletin, 120 (2), 192202. https://doiorg/101016/jmarpolbul201705014

Khan, S.A., Manokaran, S., Lyla, P.S. (2014). Assessment of ecological quality of Vellar and Uppanar estuaries, southeast coast of India, using Benthos. Indian Journal of Geo-Marine Science, 43, 1-7. http://noprniscairresin/handle/123456789/34556

Krumbein, W.C., \& Pettijohn, F.J. (1938). Manual of sedimentary petrology. Appleton, Century and Crofts, 
New York, p. 549.

Labrune, C., Amouroux, J.M., Sarda, R., Dutrieux, E., Thorin, S., Rosenberg, R., Grémare, A. (2006). Characterization of the ecological quality of the coastal Gulf of Lions (NW Mediterranean). A comparative approach based on three biotic indices. Marine Pollution Bulletin, 52 (1), 3447. https://doiorg/101016/jmarpolbul200508005

Murugesan, P., Muniasamy, M., Muthuvelu, S., Vijayalakshmi, S., Balasubramanian, T. (2011). Utility of benthic diversity in assessing the health of an ecosystem. Indian Journal of Geo-Marine Science 40, 783-793. http://noprniscairresin/handle/123456789/13265

Muxika, I., Borja, A., Bald, J. (2007). Using historical data, expert judgement and multivariate analysis in assessing reference conditions and benthic ecological status, according to the European Water Framework Directive. Marine Pollution Bulletin, 55, 16-29. https://doiorg/101016/jmarpolbul200605025

Pati, S.K., Rao, M.V., Balaji, M. (2013). Improvement in environmental parameters of a highly polluted Indian harbor. Indian Journal of Geo-Marine Science, 42(4), 487497. http://noprniscairresin/handle/123456789/20907

Pati, S. K., Rao, M.V. (2015). Fouling load in a tropical Indian harbor: spatial and temporal pattern. Journal of the Marine Biological Association of India, 57(1), 6. https://doiorg/106024/jmbai201557101693-08

Pinto, R., Patrício, J., Baeta, A., Fath, B.D., Neto, J.M., Marques, J.C. (2009). Review and evaluation of estuarine biotic indices to assess benthic condition. Ecological Indicator, 9, 1-25. https://doiorg/101016/jecolind200801005

Ram, A., Borole, D.V., Rokade, M.A., Zingde, M.D. (2009). Diagenesis and bioavailability of mercury in the contaminated sediments of Ulhas Estuary, India. Marine Pollution Bulletin 58 (11), 1685-1693. https://doiorg/101016/jmarpolbul200906021.

Ramakrishna, D.A. (2003). Manual on identification of schedule molluscs from India.

Raman, A.V., \& Ganapati, P.N. (1983). Pollution effects on ecobiology of benthic polychaetes in Visakhapatnam harbour (Bay of Bengal). Marine Pollution Bulletin, 14, 46-52. https://doiorg/101016/0025-326X(83)90190-X.

Raman, A.V., \& Ganapati, P.N. (1986). Benthic polychaete macrofauna and pollution in Visakhapatnam harbour, India. In: Mary F. Thompson, R. Sarojini and R. Nagabhushanam (Eds.), Biology of Benthic Marine Organisms, Thompson, Mary F., Sarojini, R. and Nagabhushanam, R. (Eds.), Oxford \& IBH Publishing Co., New Delhi: 463-484.

Reiss, H., \& Kröncke, I. (2005). Seasonal variability of benthic indices: an approach to test the applicability of different indices for ecosystem quality assessment. Marine Pollution Bulletin 50, 1490-1499. https://doiorg/101016/jmarpolbul200506017

Sigamani, S., Samikannu, M., Alagiri, T.G. (2019). Assessment of effluent stressed ecosystem of Cuddalore coastal waters-a bio-indicator approach. Thalassas: $A n$ International Journal of Marine Sciences 35(2): 437-449. https://doiorg/101007/s41208-019-00128-4

Sivadas, S. (2009). Impact of anthropogenic activities on macro benthic communities of west coast of India PhD, thesis, Goa University.

Sivadas, S., Nagesh, R., Gupta, G.V.M., Gaonkar, U., Mukherjee, I., Ramteke, D., Ingole, B. (2016). Testing the efficiency of temperate benthic biotic indices in assessing the ecological status of a tropical ecosystem. Marine Pollution Bulletin 106(1-2), 62-76. https://doiorg/101016/jmarpolbul201603026.

Sivaraj, S., Murugesan, P., Muthuvelu, S., Vivekanandan, K.E., Vijayalakshmi, S. (2014). AMBI and M-AMBI indices as a robust tool for assessing the effluent stressed ecosystem in Nandgaon coastal waters, Maharashtra, India. Estuarine Coastal and Shelf Science, 146, 60-67. https://doiorg/101016/jecss201405024.

Sivaraj, S., Murugesan, P., Silambarasan, A., Preetha Mini Jose, H.M., Bharathidasan, V. (2015). AMBI indices and multivariate approach to assess the ecological health of Vellar-Coleroon estuarine system undergoing various human activities. Marine Pollution Bulletin, 100, 334343. https://doiorg/101016/jmarpolbul201508028.

Subba Rao, N.V., Surya Rao, K.V., Maitra, S. (1991). Marine molluscs. State fauna series 1, Part 3. Fauna of OrissaZool. Surv. India (Kolkata). p. 1-175.

Sujata, K., Narendra Babu, K., Balasubramanian, T., Dileep Kumar, M., Sivaji P., Sundaramoorthy, S., Subramanian, B.R. (2012). Coastal Water Quality Measurements Protocol for COMAPS Programme. ICMAM Project Directorate. p.110.

Tripathy, S.C., Kusuma Kumari, B.A.V.L., Sarma, V.V., Ramana Murty, T.V. (2005). Evaluation of trophic state and plankton abundance from the environmental parameters of Visakhapatnam harbour and near-shore waters, east coast of India. Asian Journal of Microbiology, Biotechnology \& Environmental Sciences, 7 (4), 831-838. http://drsnioorg/drs/handle/2264/870

Trozzi, C., \& Vaccaro, R. (2000). Environmental impact of port activities. WIT Transactions on The Built Environment. https://doiorg/102495/PORTS000131

Venturini, N., Tommasi, L.R., Bıcego, M.C., Martins, C.C. (2004). Characterization of the benthic environment of a coastal area adjacent to an oil refinery, Todos os Santos bay (NE-Brazil). Brazilian Journal of Oceanograph, 52, 123-134.

https://doiorg/101590/S1679-87592004000200004 